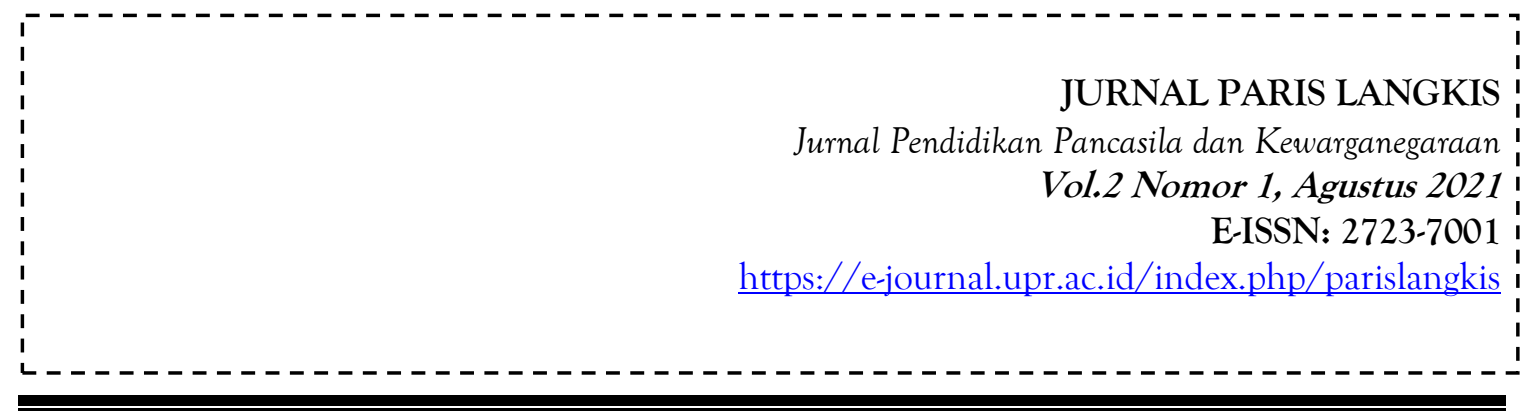

\title{
PENERAPAN LEMBAR KERJA SISWA (LKS) MATERI STATISTIKA MENGGUNAKAN METODE BRAINSTORMING DI KELAS VII MTS MIFTAHUL FALAH SUNGGAL
}

\author{
Imelda Wardani Rambe \\ STKIP Pangeran Antasari \\ E-mail: imeldawardani22@yahoo.com
}

\begin{abstract}
Abstrak
Penelitian ini bertujuan untuk mendeskripsikan efektivitas lembar kerja siswa materi statistika menggunakan Metode Brainstorming. Penelitian ini menggunakan tipe penelitian deskriptif dengan pendekatan kuantitatif. Lembar Kerja Siswa yang digunakan merupakan hasil pengembangan perangkat pembelajaran menggunakan model pengembangan 4D pada penelitian peneliti sebelumnya. Pada penelitian ini telah dilaksanakan tahap penyebaran produk peneliti sebelumnya yaitu lembar kerja siswa materi statistika yang telah valid. Lembar Kerja Siswa diterapkan ke lapangan untuk melihat efektivitasnya. Penerapan Lembar Kerja Siswa materi Statistika dilakukan pada siswa kelas VII MTs Miftahul Falah Sunggal. Instrumen penelitian berupa angket respon siswa, angket aktivitas siswa dan tes ketuntasan belajar siswa. Dari hasil penerapan di peroleh bahwa: lembar kerja siswa materi statistika menggunakan metode Brainstorming yang diterapkan efektif dilihat dari (1) ketuntasan belajar klasikal siswa terpenuhi, (2) aktivitas siswa dalam batas toleransi yang ditetapkan dan (3) respon siswa terhadap pembelajaran positif.
\end{abstract}

Kata kunci: Lembar Kerja Siswa, Metode Brainstorming, Materi Statistika

\begin{abstract}
This study aims to describe the effectiveness of student worksheets on statistical material using the Brainstorming Method. This research uses descriptive research type with quantitative approach. The Student Worksheet used is the result of developing learning tools using the 4D development model in previous research researchers. In this study, the stage of the previous research product distribution had been carried out, namely the student worksheet of valid statistical material. Student Worksheets are applied to the field to see their effectiveness. The application of the Student Worksheet on Statistics material was carried out on Grade VII students of MTs Miftahul Falah Sunggal. Research instruments in the form of student response questionnaire, student activity questionnaire and student learning completeness test. From the results of the application it was found that: student worksheets based on statistical approach to Brainstorming Method that were applied effectively were seen from (1) completeness of students' classical learning fulfilled, (2) student activities within the established tolerance limits and (3) student responses to positive learning.
\end{abstract}

Keywords : Student Worksheet, Brainstorming Method, Statistical Material

Paris Langkis

Vol.2 Nomor 1, Agustus 2021 


\section{A. PENDAHULUAN}

Statistika merupakan salah satu aspek dalam mata pelajaran matematika yang harus diberikan kepada siswa pada satuan pendidikan SMP/MTs sesuai dengan Standar Isi Permedikbud 2014. Widyantini (2008:1) menyatakan bahwa materi statistika sudah dipelajari siswa sejak Sekolah Dasar di kelas tinggi dan selanjutnya diperdalam lagi di SMP/MTs, kendala yang masih banyak dirasakan para guru adalah yang berkaitan dengan menyajikan data dalam diagram lingkaran serta mean (rata-rata) untuk pemecahan masalah, median dan modus. Siswa cenderung menghapal, tidak dapat menyelesaikan masalah/memberi alternatif penyelesaian terhadap soal yang diberikan guru.

Lembar Kerja Siswa (LKS) adalah panduan siswa yang digunakan untuk melakukan kegiatan penyelidikan atau pemecahan masalah. Trianto (2011: 223) menyatakan bahwa LKS memuat sekumpulan kegiatan mendasar yang harus dilakukan oleh siswa untuk memaksimalkan pemahaman dalam upaya pembentukan kemampuan dasar sesuai indikator pencapaian hasil belajar yang harus ditempuh. Menurut anonim (2010) LKS adalah (1) a sheet of paper used for the preliminary or rough draft of a problem, design, etc., (2) a piece of paper recording work being planned or already in progress, (3) a sheet of paper containing exercises to be completed by a pupil or student. Dapat disimpulkan bahwa LKS merupakan salah satu dari perangkat pembelajaran yang berfungsi sebagai panduan latihan pengembangan aspek kognitif maupun pengembangan semua aspek pembelajaran untuk mempermudah siswa melakukan proses-proses belajar.

Pentingnya LKS dapat dilihat dari manfaatnya dalam pembelajaran matematika. Menurut Tim Instruktur PKG (2005:10), manfaat LKS dalam pembelajaran matematika adalah : (1) Merupakan alternatif bagi guru untuk mengarahkan pengajaran atau memperkenalkan suatu kegiatan tertentu sebagai variasi belajar mengajar (Menrisal et al., 2020), (2) Dapat mempercepat pengajaran dan mempersingkat waktu penyajian materi pelajaran sebab LKS ini dapat disiapkan diluar jam pelajaran (3) Memudahkan penyelesaian tugas perorangan, kelompok, atau klasikal karena tidak setiap peserta didik dapat memahami persoalan itu pada keadaan bersamaan, (4) Mengoptimalkan penggunaan alat bantu pengajaran, (5) Membangkitkan minat belajar siswa jika LKS disusun secara menarik. Guru seyogianya mampu untuk menerapkan LKS yang valid dan efektif guna untuk membantu siswa memahami materi ajar serta dapat menyelesaikan masalah matematika yang diajukan padanya baik yang bersifat rutin ataupun tidak. Pada penelitian ini materi statistika dipahamkan ke siswa melalui media LKS. Pembelajaran melalui LKS sebagai media ajar terasa menyenangkan bila dilakukan secara diskusi, adanya komunikasi antara siswa dan guru, siswa bertanya jika mengalami kesulitan, siswa menyampaikan gagasan/ide yang dimilikinya, guru memandu proses pembelajaran, guru berperan sebagai fasilitator untuk siswa memahami materi statistika dengan media LKS yang telah valid.

Berdasarkan hal tersebut, peneliti menggunakan Metode Brainstorming demi menciptakan suasana diskusi yang menyenangkan dalam belajar memahami materi statistika dengan media LKS. Yuliani Nurani $(2003$ : 8) menyatakan bahwa metode Brainstorming sangat sesuai untuk mengumpulkan ide atau pendapat yang dikemukakan oleh seluruh siswa baik secara individual atau berkelompok, baik yang bersifat praktis 
maupun non praktis sesuai dengan permasalahan yang dibicarakan. Dengan brainstorming siswa tidak hanya akan saling melengkapi pengalaman yang luas, tetapi juga menjamin pertukaran ide dan saling mengisi. Dalam hal demikian ide seseorang akan menolong merangsang ide orang lain akhirnya menjadi arus ide yang nyata. Dalam metode ini disajikan sebuah permasalahan, lalu siswa diajak unstuck mengajukan ide apapun mengenai permasalahan itu, betapa tidak perduli betapapun anehnya ide itu, ide-ide itu tidak ditolak tetapi dianalisis dan dievaluasi.

Menurut Ayan Jordan (2002:228) agar pembelajaran ini berhasil harus mengikuti urutan empat tahap khusus yaitu (1) orientasi, (2) pembangkitan ide, (3) diskusi Dan evaluasi, (4) keputusan dan pelaksanaan. Dalam pelaksanaan metode ini tugas guru adalah memberikan masalah yang mampu merangsang pikiran siswa. Hal-Hal tersebutlah yang menjadi alasan peneliti untuk menerapkan LKS Materi Statistika menggunakan metode Brainstorming. Siswa tidak bosan dan aktif dalam belajar, langkah-langkah kegiatan pembelajaran materi statistika pada LKS dilaksanankan dengan diskusi yang menyenangkan.

Penerapan LKS ini adalah kelanjutan dari penelitian peneliti sebelumnya yaitu Pengembangan LKS Materi Statistika Berbasis Pendekatan Scientific Menggunakan Model 4D Tiagaraja. Penerapan LKS ini merupakan bagian dari salah satu tahap 4D, yaitu tahap Penyebaran. Berdasarkan Uraian diatas, tujuan penelitian ini adalah mendeskripsikan efektivitas penerapan LKS materi statistika menggunakan metode Brainstorming.

\section{B. KAJIAN TEORI}

Lembar kerja siswa adalah panduan siswa yang digunakan untuk melakukan kegiatan penyelidikan atau pemecahan masalah. Menurut Trianto (2011: 222) lembar kerja siswa dapat berupa panduan untuk latihan pengembangan aspek kognitif maupun panduan untuk pengembangan semua aspek pembelajaran dalam bentuk panduan eksperimen atau demonstrasi. Trianto (2011: 223) menambahkan LKS memuat sekumpulan kegiatan mendasar yang harus dilakukan oleh siswa untuk memaksimalkan pemahaman dalam upaya pembentukan kemampuan dasar sesuai indikator pencapaian hasil belajar yang harus ditempuh. Dapat disimpulkan bahwa LKS merupakan salah satu dari perangkat pembelajaran yang berfungsi sebagai panduan latihan pengembangan aspek kognitif maupun pengembangan semua aspek pembelajaran untuk mempermudah siswa melakukan proses-proses belajar.

Bobbi De Potter (2011) menyatakan bahwa curah gagasan (brainstorming) adalah penyelesaian masalah yang dapat digunakan baik secara individual maupun kelompok. Daryanto (2015:50) metode Brainstorming memungkinkan siswa menjadi lebih produktif dan membuat suasana belajar menyenangkan, produktivitas siswa melalui pengembangan masalah-masalah yang dipecahkan atau pengungkapan pendapat yang kreatif memungkinkan siswa dapat memahami materi secara mendalam. Menurut Karwati (dalam Rosmiati, 2013: 18) metode brainstorming yaitu memberikan kesempatan kepada siswa untuk mampu menampilkan kemandirian serta pengarahan diri, memiliki keterbukaan dan keutuhan diri dalam memilih alternatif tindakan yang terbaik, mampu menyampaikan pendapat dan mengaktualisasikan diri dalam memecahkan suatu masalah serta mampu menghargai pendap orang lain.

Paris Langkis

Vol.2 Nomor 1, Agustus 2021 


\section{METODE PENELITIAN}

Penelitian ini adalah tipe penelitian Deskriptif dengan pendekatan kuantitatif. Penelitian dilaksanakan di MTs Swasta Miftahul Falah Sunggal Tahun Ajaran 2019/2020. Subjek dalam penelitian ini adalah siswa kelas VII-1 MTs Miftahul Falah Sunggal berjumlah 26 orang dan objek dalam penelitian ini adalah penerapan lembar kerja siswa materi statistika menggunakan metode Brainstorming.

Instrumen penelitian dan teknik pengumpulan data disusun untuk mengukur efektivitas lembar kerja siswa materi statistika menggunakan metode Brainstorming. Instrumen yang digunakan dalam penelitian ini adalah (1) lembar tes kemampuan siswa yaitu posttest (2) lembar pengamatan aktivitas siswa, (3) angket respon siswa. Teknik analisis data yang digunakan dalam penelitian ini adalah analisis statistik deskriptifkuantitatif. Rancangan penerapan yang akan digunakan dalam penelitian ini adalah oneshot case study atau disebut juga dengan one-group posttest-only design (Setyosari, 2012: 174).

Efektivitas lembar kerja siswa materi statistika yang diterapkan menggunakan metode Brainstorming dicapai pada 3 indikator yaitu ; respon siswa, persentase waktu ideal aktivitas siswa dan ketuntasan belajar siswa secara klasikal. Persentase respon siswa dan aktivitas siswa dihitung dengan menggunakan rumus (Trianto, 2011:243). Persentase respon siswa yaitu Proporsional siswa yang memilih dibagi Jumlah siswa (responden)dikali $100 \%$. Kriterianya adalah jika 80\% atau lebih siswa merespon dalam kategori positif maka respon siswa dikatakan positif. Persentase aktivitas siswa $(P)$ yaitu frekuensi setiap aspek pengamatan dibagi dengan jumlah frekuensi semua aspek pengamatan dikali 100 $\%$. Ketuntasan belajar siswa dapat dianalisis dengan cara membandingkan rata-rata skor siswa yang diperoleh dari hasil tes uji coba. Siswa dapat dikatakan tuntas apabila nilai siswa secara individual mencapai 2,67. Selanjutnya, suatu pembelajaran dikatakan telah tuntas secara klasikal yaitu terdapat $85 \%$ siswa yang mengikuti tes telah mencapai skor minimal 2,67 (Permendikbud, 2014).

\section{HASIL DAN PEMBAHASAN}

Lembar Kerja Siswa Materi Statistika menggunakan metode Brainstorming yang telah diterapkan di kelas VII-1 MTs Swasta Miftahul Falah Sunggal terbukti efektif. Hal ini ditunjukkan dengan tercapainya ketiga indikator efektivitas. Indikator pertama yaitu ketuntasan belajar siswa secara klasikal terpenuhi. Berikut hasil tes matematis siswa materi statistika. 


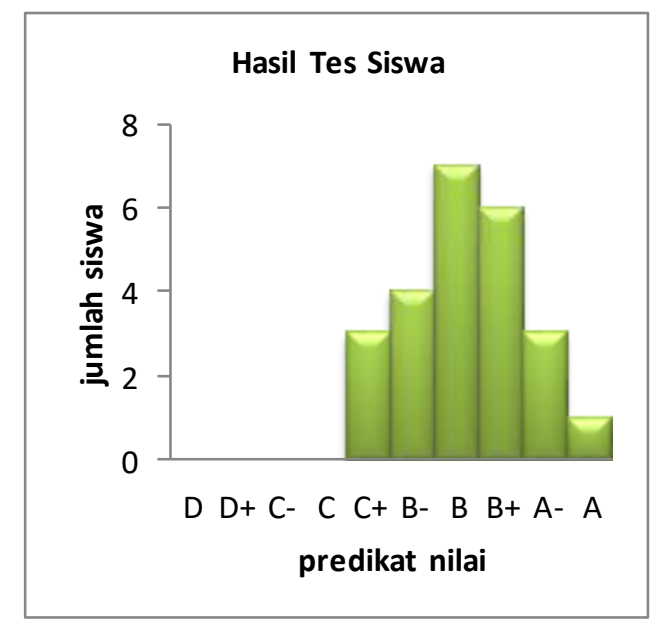

\section{Gambar 1. Hasil Tes Matematis Siswa}

Jumlah siswa yang memperoleh nilai C+ sebanyak 3 siswa (11,54\%), yang memperoleh B- sebanyak 4 siswa (15,38\%), yang memperoleh B sebanyak 7 siswa (26,92\%), yang memperoleh $\mathrm{B}^{+}$sebanyak 6 siswa (23,08\%), yang memperoleh $\mathrm{A}$ sebanyak 3 siswa (11,54\%), yang memperoleh A sebanyak 1 siswa $(3,84 \%)$. Jumlah siswa yang telah tuntas belajar secara klasikal dengan mencapai nilai minimum prediket Badalah sebanyak 23 siswa $(88,46 \%)$ dari 26 siswa yang mengikuti pembelajaran. Berdasarkan kriteria yang telah ditetapkan, disimpulkan bahwa ketuntasan belajar secara klasikal telah tercapai. Indikator kedua yaitu aktivitas siswa berada dalam batas waktu toleransi yang ditetapkan.

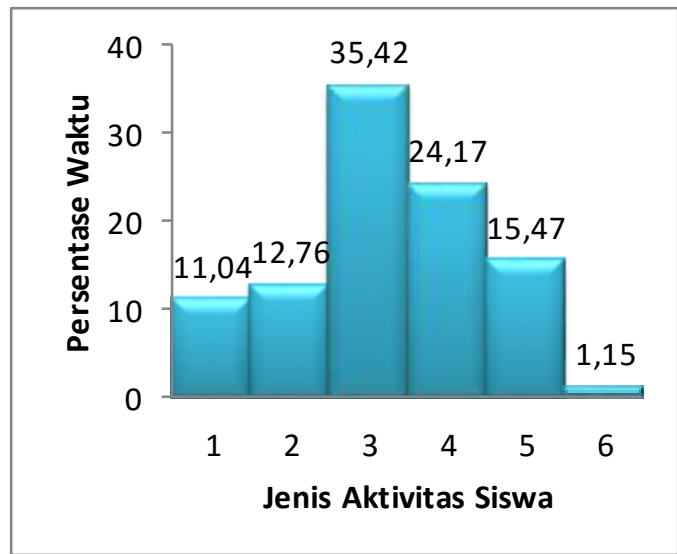

Gambar 2. Persentase Waktu Akrivitas Siswa.

Jika rerata persentase waktu aktivitas siswa masing-masing kategori dirujuk pada kriteria penentuan ketercapaian persentase waktu ideal aktivitas siswa, maka dapat disimpulkan bahwa persentase waktu aktivitas siswa memenuhi pencapaian persentase waktu ideal atau berada pada interval toleransi waktu kategori aktivitas siswa yang ditetapkan. Indikator ketiga yaitu respon siswa terhadap pembelajaran positif.

Tabel 1. Hasil Angket Respon Siswa

\begin{tabular}{|l|l|l|l|}
\hline No & Aspek yang direspon & \multicolumn{2}{|l|}{ Persentase $(\%)$} \\
\hline & & Jelas & $\begin{array}{l}\text { Tidak } \\
\text { Jelas }\end{array}$ \\
\hline
\end{tabular}




\begin{tabular}{|c|c|c|c|}
\hline \multirow[t]{6}{*}{1.} & $\begin{array}{l}\text { Perasaan siswa terhadap komponen } \\
\text { pembelajaran: }\end{array}$ & & \\
\hline & a. Materi Ajar & $91 \%$ & $9 \%$ \\
\hline & b. LKS & $100 \%$ & - \\
\hline & c. Suasana Pembelajaran di kelas & $91 \%$ & $9 \%$ \\
\hline & d. Cara guru mengajar & $100 \%$ & - \\
\hline & & Baru & $\begin{array}{l}\text { Tidak } \\
\text { Baru }\end{array}$ \\
\hline \multirow[t]{6}{*}{2.} & $\begin{array}{l}\text { Pendapat siswa terhadap komponen } \\
\text { pembelajaran: }\end{array}$ & & \\
\hline & a. Materi ajar & $91 \%$ & $9 \%$ \\
\hline & b. LKS & $100 \%$ & - \\
\hline & c. Suasana Pembelajaran di kelas & $100 \%$ & - \\
\hline & d. Cara guru mengajar & $100 \%$ & - \\
\hline & & Berminat & $\begin{array}{l}\text { Tidak } \\
\text { Berminat }\end{array}$ \\
\hline \multirow[t]{2}{*}{3.} & $\begin{array}{l}\text { Pendapat siswa tentang minat untuk } \\
\text { mengikuti pelajaran selanjutnya } \\
\text { dengan pendekatan Scientific }\end{array}$ & $100 \%$ & - \\
\hline & & Jelas & $\begin{array}{l}\text { Tidak } \\
\text { Jelas }\end{array}$ \\
\hline \multirow[t]{3}{*}{4.} & $\begin{array}{l}\text { Pendapat siswa tentang pemahaman } \\
\text { bahasa yang digunakan dalam: }\end{array}$ & & \\
\hline & a. LKS & $91 \%$ & $9 \%$ \\
\hline & & Tertarik & $\begin{array}{l}\text { Tidak } \\
\text { Tertarik }\end{array}$ \\
\hline \multirow[t]{2}{*}{5.} & $\begin{array}{l}\text { Pendapat siswa tentang penampilan } \\
\text { (tilisan, ilustrasi/gambar dan letak } \\
\text { gambar) yang ada dalam: }\end{array}$ & & \\
\hline & a. LKS & $91 \%$ & $9 \%$ \\
\hline
\end{tabular}

Dari data menunjukkan bahwa respon siswa terhadap semua aspek LKS materi statistika menggunakan metode Brainstorming berada di atas $80 \%$. Jika hasil ini dirujuk pada kriteria yang ditetapkan, dapat disimpulkan bahwa respon siswa terhadap LKS tersebut adalah positif.

Hasil analisis data adalah sebagai berikut: (1) Ketuntasan belajar siswa secara klasikal tercapai; (2) kadar aktivitas aktif siswa mencapai kriteria batas waktu toleransi; (3) angket respon siswa pada setiap komponen dan kegiatan pembelajaran adalah positif. Jika simpulan hasil analisis data pada ini dirujuk pada kriteria yang ditetapkan, maka dapat disimpulkan bahwa produk Lembar Kerja Siswa materi statistika menggunakan metode Brainstorming telah memenuhi kriteria keefektifan untuk diterapkan.

\section{E. SIMPULAN DAN SARAN}

Berdasarkan hasil analisis data menunjukkan bahwa Lembar Kerja Siswa Materi Statistika menggunakan metode Brainstorming efektif diterapkan di kelas VII MTs Bayu 
Pertiwi Sunggal. Berdasarkan simpulan penelitian di atas, pembelajaran materi statistik dengan menggunakan lembar kerja siswa menggunakan metode Brainstorming yang diterapkan pada kegiatan pembelajaran memberikan beberapa hal yang penting untuk diperhatikan. Untuk itu peneliti menyarankan beberapa hal sebagai berikut: (1) Lembar Kerja Siswa yang diterapkan ini adalah produk hasil penelitian pengembangan perangkat pembelajaran peneliti sebelumnya, baru sampai pada tahap penyebaran terbatas, belum diimplementasikan secara luas di sekolah-sekolah, (2) Untuk mengetahui efektivitas lembar kerja siswa menggunakan metode Brainstorming dalam berbagai topik pelajaran matematika dan mata pelajaran lain yang sesuai, disarankan pada para guru dan peneliti untuk mengimplementasikan lembar kerja siswa ini pada ruang lingkup yang lebih luas di sekolah-sekolah.

\section{F. DAFTAR PUSTAKA}

Anonim. 2010. Student Worksheet Definitions.

http://www.contentextra.com/bacconline/OnlineResources/

Bistari. 2010. Pengembangan Kemandirian Belajar Berbasis Nilai untuk Meningkatkan Komunikasi Matematik. Jurnal Pendidikan Matematika dan Ipa Vol. 1 No. 1 Januari 2010, hal. 11-23

Daryanto. 2015. Teori Belajar dan Proses Pembelajaran yang Mendidik. Jakarta: Gava Media

De Porter, B. dan Hernacki, M. 2011. Quantum Learning. Jakarta : Kaifa

Jordan, Ayan. 2002. Bengkel Kreativitas. Bandung : Kaifa

Rosmiati. 2013. Penerapan Metode Pembelajaran Brainstorming untuk Meningkatkan Kemampuan Berpikir Kritis Peserta Didik. Skripsi. Sarjana Pada FPIPS UPI Bandung. Tidak Diterbitkan.

Setyosari. 2010. Metode Penelitian Pendidikan dan Pengembangan. Jakarta: Prenada Mediagroup

Tim MKPBM Jurusan Pendidikan Matematika. 2004. Strategi Belajar Matematika kontemporer, Jakarta: JICA Universitas Pendidikan Indonesia

Trianto. 2011. Mendesain Model Pembelajaran Inovatif- Progresif. Jakarta : Kencana.

Thiagarajan, S. Semmel, D.S. Semmel, M. 1974. Instructional Development for Training Teachers of Exceptional Children. A Sourse Book. Blomington: Central for Innovation on Teaching The Handicapped.

Varelas, M and Ford M. 2009. The scientific method and scientific inquiry: Tensions in teaching and learning. USA: Wiley InterScience.

Widyantini. 2008. Permasalahan Pembelajaran Statistika-Peluang SMP. Yogyakarta: Pusat Pengembangan dan Perbedayaan Pendidik dan Tenaga Kependidikan Matematika.

Yuliani, Nurani. 2003. Strategi Pembelajaran. Jakarta : Pusat Penerbitan Universitas Terbuka. 